\title{
Cancer mortality in the British rubber industry
}

\author{
H G PARKES, C A VEYS, J A H WATERHOUSE, AND ANN PETERS
}

\begin{abstract}
From the British Rubber Manufacturers' Association, Health Research Unit, Birmingham, and the Cancer Epidemiology Research Unit, Department of Social Medicine, the University of Birmingham, Birmingham, UK
\end{abstract}

ABSTRACT Although it is over 30 years since an excess of bladder cancer was first identified in British rubber workers, the fear has persisted that this hazard could still be affecting men working in the industry today. Furthermore, suspicions have also arisen that other and hitherto unsuspected excesses of cancer might be occurring. For these reasons 33815 men, who first started work in the industry between 1 January 1946 and 31 December 1960, have been followed up to 31 December 1975 to ascertain the number of deaths attributable to malignant disease and to compare these with the expected number calculated from the published mortality rates applicable to the male population of England and Wales and Scotland. The findings confirm the absence of any excess mortality from bladder cancer among men entering the industry after 1 January 1951 (the presumed bladder carcinogens were withdrawn from production processes in July 1949), but they confirm also a statistically significant excess of both lung and stomach cancer mortality. A small excess of oesophageal cancer was also observed in both the tyre and general rubber goods manufacturing sectors. American reports of an excess of leukaemia among rubber workers receive only limited support from the present study, where a small numerical excess of deaths from leukaemia is not statistically significant. A special feature of the study is the adoption of an analytical method that permits taking into account the long latent period of induction of occupational cancer.

The existence of an occupational bladder cancer hazard has been recognised in the British rubber industry since $1950^{1-4}$; the current position has recently been reviewed by one of us. ${ }^{5}$ During the early 1970 s epidemiological studies were extended on both sides of the Atlantic to the investigation of the total mortality pattern of rubber workers, but with special emphasis on deaths from cancer. It has for some time been suggested that other and hitherto unsuspected excesses of cancer could also be present in addition to the recognised excess of occupational bladder cancer. Unpublished preliminary observations using proportional mortality data collected in the course of a study of bladder cancer by the British Rubber Manufacturers' Association (BRMA) did provide some evidence of an excess of both lung and stomach cancers.

On 1 February 1967 a survey $^{6}$ was set up by the then senior medical inspector of factories to determine whether there was a continuing risk of bladder cancer in the rubber and cable-making industries. On that date a detailed census was undertaken in

Received 13 November 1981

Accepted 14 December 1981
381 factories, enumerating all men aged 35 years and over who had been employed for one year or more. Interim and final reports have since been published. $^{7-9}$

In the United States during 1970-2 six major rubber companies agreed, together with the United Rubber Workers of America, to begin studies on the health effects of the work environment. Studies of one group of major United States rubber manufacturing plants were undertaken by the department of epidemiology at the Harvard School of Public Health in Boston and were subsequently extensively reported. ${ }^{10-15}$ In addition, but independently, the occupational health studies group from the School of Public Health, the University of North Carolina at Chapel Hill, undertook studies of male (and in some instances female) workers in other rubber manufacturing plants. Their findings have also been reported. ${ }^{16-26} \mathrm{~A}$ combined study and review by both groups on bladder cancer in the United States rubber industry has recently been published. ${ }^{27}$

In the United Kingdom after due consultation with management and unions, the BRMA, in collaboration with the cancer epidemiology research unit 
of the department of social medicine at Birmingham University began their own study of 13 large rubber factories, predominantly engaged in producing tyres and tubes, but also incorporating some general rubber goods manufacture. The results of the BRMA study were initially reported to the industry in $1976^{28}$ and subsequently in medical publications. ${ }^{29}$

The purpose of the present study has been to investigate and identify any occupational cancer hazard (in addition to that of occupational bladder cancer) that might currently be affecting men employed in the industry. The study consolidates the data from earlier work and incorporates a further follow-up of the workforce to 31 December 1975. It analyses and evaluates mortality from cancer as the underlying cause of death. This investigation takes account of the long latent period of induction of occupational cancers, and the analytical method adopted is designed to highlight any association-if such exists-between the disease and the antecedent work history. This is achieved by excluding from the analysis those deaths from cancer that are least likely to be related to the working environment. The technique requires simply that observations on the life experience of men qualifying for inclusion be deferred for the period of the latent interval chosen. It is therefore a special feature of this study that each participant must survive a minimum qualifying 10-year latency interval after entering into employment before being accepted for inclusion in the statistical analysis. Thus all individuals who died within this qualifying period have been excluded from the analysis. Those men eliminated from the study population on the latency criteria included, in addition to those who died within 10 years of engagement, a substantial proportion $(58 \%)$ of those who have been lost to follow-up (largely as a result of emigration).

\section{Methods}

The structure of the industry population is shown in tables 1 and 2. Table 1 shows that a total of 33815 men met the criteria for inclusion in the study population. The tabulation indicates the distribution of this population by cohort and within the principal product and geographical subdivisions. The rapid expansion of the industry during the immediate postwar years accounts for the disparity in the numerical size of the cohorts that reflects the level of intake of new employees into the industry in the three quinquennia 1946-50, 1951-5, and 1956-60. The preponderance of the population is located within the tyre factories in England and only $15 \%$ of all employees studied were engaged in manufactur- ing general rubber goods.

At the outset the study population numbered 36695 and consisted of all male operatives entering any one of the 13 participating factories between 1946 and 1960, provided that they had worked continuously in the industry for a minimum of one year. From the total thus enumerated the final study population of 33815 was defined. This includes only those men known to have survived the minimum further period of nine years after the first qualifying year, before death or before being lost to follow-up, thereby fulfilling the latency criteria. The same criteria were subsequently applied to the analysis of cancer mortality by occupation or, put in another way, the date of first employment in any job category had to be at least 10 years before death.

Several factors determined the choice of 1 January 1946 as the study start-date. These were the postwar build-up of factory labour forces and the need to define an "at-risk" group of men first employed at a time when the now recognised bladder carcinogens were being used in processing. It was also necessary to go sufficiently far back to accommodate the inherently long latent period of cancer induction, in order to make any analysis meaningful. Finally, the advantages for subsequent tracing of using the newly introduced documentation for National Health Service (NHS) and National Insurance (NI) registration were important considerations. The analytical epidemiological design is that of a retrospective cohort study ${ }^{30}$ with further prospective follow-up envisaged. A study end-date of 31 December 1975 has been defined for this analysis, although the study continues.

Factory records have been used to confirm the status of those currently employed or retired on pension at the study end-date; and to the extent that it has been possible to do so, all individuals who left before retirement have also been followed up. A first screening of these was made through the social security division of the DHSS in Newcastle upon Tyne

Table 1 Study population by cohort

\begin{tabular}{lrrrr}
\hline & Cohort I & Cohort II & Cohort III & All cohorts \\
\hline Tyre & & & & \\
$\quad$ England & 10861 & 7380 & 6514 & 24755 \\
$\begin{array}{l}\text { Scotland } \\
\text { Total }\end{array}$ & 2268 & 1035 & 684 & 3987 \\
General rubber & 13129 & 8415 & 7198 & 28742 \\
goods & & & & \\
$\quad$ England & 1914 & 1469 & 1048 & 4431 \\
$\quad$ Scotland & 163 & 231 & 248 & 642 \\
Total & 2077 & 1700 & 1296 & 5073 \\
Grand total & 15206 & 10115 & 8494 & 33815 \\
\hline
\end{tabular}

Cohort I = Men entering the industry 1946-50.

Cohort II = Men entering the industry 1951-5.
Cohort III $=$ Men entering the industry 1956-60. 
using the NI number. A subsequent screening in England was made through the Office of Population Censuses and Surveys (OPCS) using the NHS number and the facilities of the Central Registry at Southport. In Scotland men were traced through the General Register Office. Where the records showed that an individual had died, details of the death certificate were provided either by these two offices, or from factory (pensions) records, and sometimes from local authority archives. Much valuable help was given by the Health and Safety Executive (HSE) who collaborated with the BRMA in tracing men who featured in both studies. The death certificates obtained from these sources were coded to the underlying cause, using the rules and revisions of the International Classification of Diseases (ICD) appertaining at the time of death. ${ }^{31}$ In addition all deaths from cancer were recoded to the eighth revision of the ICD for the purposes of this analysis (see below).

All the data were checked, transcribed on to punched cards, and computerised for analysis. The entry for each man consisted of full name; date of birth; date of entering or leaving employment; the last date known to be alive, or the date of death; and full details of the occupational history. The work history at the relevant factory was coded by the factory personnel concerned, and the record incorporated all job changes with relevant dates. Jobs were coded into one of ten categories, as defined by Parkes $^{32}$ (table 2). In this and in the analyses that record deaths from cancer by job category, an individual may feature in one or more job categories because the total work history is being studied. The essential criterion was that the 10 years' latency qualification for that particular job code had to be met. Numbers of deaths listed in the tables analysing job categories are, therefore, not additive because they are not mutually exclusive and they cannot be totalled.

Person-years at risk using the actual life experience have been calculated according to the method of Hill $^{33}$ but the first 10 years since the date of first employment were excluded. Subsequent calculations, taking quinary/quinquennial groupings (age and time respectively), were made to compute the expected number of deaths by applying the appropriate national age-specific mortality rates to the man-years at risk for the relevant period. The observed number of deaths from all causes, all neoplasms, and several individual cancer sites were then compared with those expected at these national rates. For the factories in England national mortality rates (for individual cancers and for all deaths), published by OPCS $^{34}$ and based on the Case-Pearson tables, were used in calculating the expected deaths.
Table 2 Study population: occupation groups

\begin{tabular}{|c|c|c|c|}
\hline \multirow[t]{2}{*}{ Group } & \multirow[t]{2}{*}{ Description } & \multicolumn{2}{|c|}{ No in study population } \\
\hline & & Original & $\begin{array}{l}\text { After allowance } \\
\text { for latency }\end{array}$ \\
\hline $\begin{array}{l}1 \\
2\end{array}$ & $\begin{array}{l}\text { Crude material storeman } \\
\text { Compounding, weighing, } \\
\text { mixing, reforming, } \\
\text { washing, etc }\end{array}$ & $\begin{array}{r}546 \\
3203\end{array}$ & $\begin{array}{r}507 \\
2951\end{array}$ \\
\hline 3 & $\begin{array}{l}\text { Latex mixing, frothing, } \\
\text { dipping }\end{array}$ & 1590 & 1492 \\
\hline 4 & $\begin{array}{l}\text { Extruding, calendering, } \\
\text { spreading, etc }\end{array}$ & 3840 & 3596 \\
\hline 5 & $\begin{array}{l}\text { Component bulding, } \\
\text { preparation, assembly, } \\
\text { etc }\end{array}$ & 15371 & 14463 \\
\hline 6 & $\begin{array}{l}\text { Vulcanising, curing, } \\
\text { moulding press, } \\
\text { autoclave, pan }\end{array}$ & 5599 & 5191 \\
\hline 7 & $\begin{array}{l}\text { Inspection, painting, } \\
\text { trimming, etc }\end{array}$ & 1874 & 1771 \\
\hline 8 & $\begin{array}{l}\text { Finished goods, stores, } \\
\text { packaging, despatch }\end{array}$ & 2346 & 2190 \\
\hline 9 & $\begin{array}{l}\text { Site workers, internal } \\
\text { transport, general truck } \\
\text { drivers, etc }\end{array}$ & 2240 & 1909 \\
\hline \multirow[t]{2}{*}{10} & $\begin{array}{l}\text { Engineering and } \\
\text { building maintenance }\end{array}$ & 6646 & 6171 \\
\hline & $\begin{array}{l}\text { All occupation groups } \\
\text { combined }\end{array}$ & $36695^{*}$ & $33815^{*}$ \\
\hline
\end{tabular}

${ }^{*}$ This figure is not the sum total of the individual occupation groups.

These rates are based on deaths coded to the eighth revision and traced backwards for continuity, which is why all the death certificates used in this study were also so coded. Where required, to supplement the analyses for all causes and for deaths from cancer occurring from 1971 to 1975 , additional material was drawn from the annual series of the Registrar General's Statistical Review of England and Wales and other OPCS publications. ${ }^{35}$ For Scotland, the relevant serial mortality tables were used ${ }^{36}$ together with mortality data published by the Registrar General for Scotland in various annual reports.

Although most participating factories are located in highly urban areas, or in conurbations exhibiting pronounced regional variations for some of the cancer sites studied, no adjustments for such factors nor for those relating to social class have been attempted.

The difference between the observed and expected deaths was examined by calculating a significance level ( $p$ value) for the observed numbers of deaths. Where the expected number of deaths is greater than five the difference between observed and expected has been tested by $\chi^{2}$ with one degree of freedom ${ }^{37}$; where the expected number is less than five, the Poisson distribution has been used to determine the significance of any observed excess.

Standardised mortality ratios (SMRs) were not calculated throughout, since in some cases the num- 
bers of deaths expected were too small for these to be a meaningful indicator of the level of risk. For convenience, SMRs shown in the tables have been rounded to whole numbers.

\section{Results}

At the study end-date of 31 December 19754882 men had been traced as dead and 28410 as living (table 3). A total of 523 men remained untraced, giving a successful follow-up rate of $98.5 \%$. Untraced men (including those who emigrated) were included in the analysis up to the time of being lost to follow-up.

\section{ALL CAUSES OF DEATH}

The present study is concerned only with the observation of deaths from malignant disease and for that reason the data have been derived from a population that meets the latency criteria already defined. It would not be appropriate to apply the same criteria to a study of deaths from all causes-which would include, for example, deaths from accident and acute disease-since these deaths would not be subject to the latency influence. Before the application of the latency criteria the study population numbered 36695 men and there were 6340 deaths recorded from all causes (expected 6504) within that population. In the present study the population was reduced by the application of the latency criteria to 33815 , and the total number of deaths from all causes was recorded as 4882 (expected 4841). This observation suggests that the "healthy worker effect," giving rise to a deficit in the number of observed deaths, is largely dissipated by a ten-year period of employment.

\section{CANCER MORTALITY ANALYSIS}

Cancer mortality* has been analysed in this study by date of entry into the industry-that is, by cohortby industry product group, such as tyre or general rubber goods manufacture, and by occupation within those product groups. On the strength of evidence derived from other epidemiological studies of rubber workers it was decided to provide data for a wide range of selected cancer sites, but the present study is concerned chiefly with the more detailed investigation of lung, stomach, and bladder cancer mortality as the incidence of these tumours is either of historical interest or a matter of current concern.

\footnotetext{
* Cancer mortality in this study includes deaths from all causes listed under eighth revision ICD codes 140-239. Deaths from leukaemia are therefore included as are also a total of 10 deaths attributed to benign or unspecified benign/malignant neoplasms. Six of these 10 deaths resulted from tumours of the brain.
}

Table 3 Status of study population at study end-date 31 December 1975

\begin{tabular}{lrr}
\hline & No & $\%$ \\
\hline Traced & & \\
$\quad$ Alive and still at work in industry & 7143 & $21 \cdot 1$ \\
Alive and left employment & 21267 & $62 \cdot 9$ \\
Dead: cause known & 4826 & $14 \cdot 3$ \\
Dead: cause unknown & 56 & $0 \cdot 2$ \\
& & \\
Lost to follow-up & & \\
$\quad$ Emigrated & 406 & $1 \cdot 2$ \\
$\quad$ Untraced & 117 & $0 \cdot 3$ \\
Total & 33815 & $100 \cdot 0$ \\
\hline
\end{tabular}

\section{ALL CANCERS}

During the study period there was a total of 1359 recorded cancer deaths compared with 1221 expected $(p<0.001)$. The excess deaths were, however, not evenly distributed among the three cohorts, being observed only in cohorts I and III (table 4). The largest excess $(S M R=144)$ is recorded in cohort I within the general rubber goods sector, but significant excesses are shown also in the tyre sector in both cohorts I and III (the cohort III excess occurs only in the tyre sector).

When cancer mortality is examined within each of the 10 occupation subgroups there is once again a divergence between the experience of those employed in the tyre industry and those making general rubber goods (table 5). The figures for the whole industry indicate that occupation groups $5,6,7$, and 9 are those chiefly responsible for the excess cancers, and this pattern is reflected in the tyre sector where significant excesses arise in occupation groups 6,7 , and 9 . In the general rubber goods sector only occupation group 2 has a significant excess of cancer, although raised SMRs are recorded for all occupation groups except groups 3 and 9 .

Table 6 shows the distribution of cancer mortality by tumour site and by industry product group. From this it is apparent that the excess cancer mortality in the industry is accounted for almost entirely by an excess of lung and stomach cancer to be found both in the tyre and in the general rubber goods sectors. The high SMRs recorded in the general rubber goods sector (154 for lung cancer and 145 for stomach cancer) compare unfavourably with those in the tyre industry (118 for lung and 126 for stomach cancer).

\section{LUNG CANCER}

The detailed analysis of lung cancer mortality (table 7) shows that almost all of the industry excess $(\mathrm{O}=638 \mathrm{E}=517.4 \mathrm{p}<0.01)$ is located within cohort I (tyre sector: $O=348 \mathrm{E}=279.8 \mathrm{p}<0.001$ : general rubber_goods sector: $\mathrm{O}=84 \mathrm{E}=46.4$ 
Table 4 Cancer mortality: all neoplasms by cohort. (ICD-8: 140-239)

\begin{tabular}{|c|c|c|c|c|c|c|c|c|c|c|c|c|}
\hline & \multicolumn{3}{|c|}{ Cohort I } & \multicolumn{3}{|c|}{ Cohort II } & \multicolumn{3}{|c|}{ Cohort III } & \multicolumn{3}{|l|}{ Total } \\
\hline & $O b s$ & $\operatorname{Exp}$ & $S M R$ & Obs & $\operatorname{Exp}$ & $S M R$ & $O b s$ & $\operatorname{Exp}$ & $S M R$ & Obs & $\operatorname{Exp}$ & $S M R$ \\
\hline $\begin{array}{l}\text { Tyre } \\
\text { General rubber } \\
\text { goods }\end{array}$ & $\begin{array}{l}730^{* *} \\
159^{* * *}\end{array}$ & $\begin{array}{l}657 \cdot 7 \\
110 \cdot 2\end{array}$ & $\begin{array}{l}111 \\
144\end{array}$ & $\begin{array}{r}265 \\
55\end{array}$ & $\begin{array}{r}270.7 \\
58.6\end{array}$ & $\begin{array}{l}98 \\
94\end{array}$ & $\begin{array}{c}130^{*} \\
20\end{array}$ & $\begin{array}{r}104.7 \\
19.3\end{array}$ & $\begin{array}{l}124 \\
104\end{array}$ & $\begin{array}{c}1125^{* *} \\
234^{* * *}\end{array}$ & $\begin{array}{r}1033 \cdot 1 \\
187 \cdot 9\end{array}$ & $\begin{array}{l}109 \\
125\end{array}$ \\
\hline Total & $889^{* * *}$ & 767.9 & 116 & 320 & 329.3 & 97 & $150^{*}$ & $124 \cdot 0$ & 121 & $1359^{* * *}$ & $1221 \cdot 0$ & 111 \\
\hline
\end{tabular}

${ }^{*} \mathrm{p}<0.05$. $^{* *} \mathrm{p}<0.01 .{ }^{* * *} \mathrm{p}<0.001$.

Table 5 Cancer mortality: all neoplasms by occupation group (all cohorts combined). (ICD-8: 140-239)

\begin{tabular}{|c|c|c|c|c|c|c|c|c|c|}
\hline \multirow[t]{2}{*}{ Occupation group } & \multicolumn{3}{|l|}{ Tyre } & \multicolumn{3}{|c|}{ General rubber goods } & \multicolumn{3}{|l|}{ Total } \\
\hline & $\overline{O b s}$ & $\operatorname{Exp}$ & $\overline{S M R}$ & Obs & $\operatorname{Exp}$ & $\overline{S M R}$ & Obs & $\operatorname{Exp}$ & $S M R$ \\
\hline $\begin{array}{r}1 \\
2 \\
3 \\
4 \\
5 \\
6 \\
7 \\
8 \\
9 \\
10\end{array}$ & $\begin{array}{c}19 \\
91 \\
37 \\
102 \\
416 \\
154^{*} \\
53^{* *} \\
83 \\
114^{* *} \\
194^{*}\end{array}$ & $\begin{array}{r}15.4 \\
88 \cdot 9 \\
47 \cdot 5 \\
90 \cdot 6 \\
382.8 \\
129.3 \\
34.9 \\
76 \cdot 1 \\
86 \cdot 1 \\
207 \cdot 2\end{array}$ & $\begin{array}{r}123 \\
102 \\
78 \\
113 \\
109 \\
119 \\
152 \\
109 \\
132 \\
94\end{array}$ & $\begin{array}{c}5 \\
34^{*} \\
5 \\
34 \\
59 \\
41 \\
14 \\
14 \\
13 \\
43\end{array}$ & $\begin{array}{r}4 \cdot 1 \\
24 \cdot 1 \\
5 \cdot 3 \\
29 \cdot 2 \\
49 \cdot 1 \\
30 \cdot 8 \\
10 \cdot 2 \\
9 \cdot 7 \\
13 \cdot 2 \\
33 \cdot 2\end{array}$ & $\begin{array}{r}122 \\
141 \\
94 \\
116 \\
120 \\
133 \\
137 \\
144 \\
98 \\
130\end{array}$ & $\begin{array}{c}24 \\
125 \\
42 \\
136 \\
475^{*} \\
195^{* *} \\
67^{* *} \\
97 \\
127^{* *} \\
237\end{array}$ & $\begin{array}{r}19.5 \\
113.1 \\
52.8 \\
119.8 \\
431.9 \\
160.1 \\
45.1 \\
85.8 \\
99.2 \\
240.3\end{array}$ & $\begin{array}{r}123 \\
111 \\
80 \\
114 \\
110 \\
122 \\
149 \\
113 \\
128 \\
99\end{array}$ \\
\hline All jobs & $1125^{* *}$ & $1033 \cdot 1$ & 109 & $234^{* * * *}$ & 187.9 & 125 & $1359^{* * *}$ & $1221 \cdot 0$ & 111 \\
\hline
\end{tabular}

${ }^{*} \mathrm{p}<0.05$. $^{* *} \mathrm{p}<0.01$. $^{* * *} \mathrm{p}<0.001$.

Table 6 Cancer mortality: all neoplasms by cancer site for tyre and general rubber goods sectors. (ICD—8: 140-239)

\begin{tabular}{|c|c|c|c|c|c|c|c|c|c|c|}
\hline \multirow[t]{2}{*}{ Neoplasm } & \multicolumn{4}{|c|}{ ICD eighth revision code Tyre } & \multicolumn{3}{|c|}{ General rubber goods } & \multicolumn{3}{|c|}{ Whole industry } \\
\hline & & $O b s$ & $\operatorname{Exp}$ & $S M R$ & $O b s$ & $\operatorname{Exp}$ & $S M R$ & Obs & $\operatorname{Exp}$ & $S M R$ \\
\hline $\begin{array}{l}\text { Lung } \\
\text { Stomach } \\
\text { Bladder } \\
\text { Prostate } \\
\text { Thyroid } \\
\text { Colon } \\
\text { Rectum } \\
\text { Leukaemia } \\
\text { Oesophagus } \\
\text { Brain } \\
\text { Others }\end{array}$ & $\begin{array}{l}162 \cdot 1,163 \cdot 0,163 \cdot 9 \\
151 \\
188,189 \cdot 9 \\
185 \\
193 \\
153 \\
154 \\
204-207 \\
150 \\
191,192,224,225,238\end{array}$ & $\begin{array}{c}515^{* * *} \\
151^{* * *} \\
33 \\
24 \\
4 \\
55 \\
44 \\
26 \\
30 \\
32 \\
211\end{array}$ & $\begin{array}{r}437 \cdot 7 \\
119 \cdot 7 \\
36 \cdot 1 \\
38 \cdot 1 \\
2 \cdot 0 \\
62 \cdot 5 \\
45 \cdot 7 \\
23 \cdot 8 \\
27 \cdot 0 \\
35 \cdot 0 \\
205 \cdot 5\end{array}$ & $\begin{array}{r}118 \\
126 \\
91 \\
63 \\
200 \\
88 \\
96 \\
109 \\
111 \\
91 \\
103\end{array}$ & $\begin{array}{c}123^{* * *} \\
32^{*} \\
3 \\
6 \\
0 \\
12 \\
6 \\
5 \\
10^{*} \\
3 \\
34\end{array}$ & $\begin{array}{r}79 \cdot 7 \\
22 \cdot 1 \\
6 \cdot 8 \\
7 \cdot 4 \\
0 \cdot 3 \\
11 \cdot 2 \\
8 \cdot 4 \\
4 \cdot 3 \\
4 \cdot 8 \\
6 \cdot 1 \\
36 \cdot 8\end{array}$ & $\begin{array}{r}154 \\
145 \\
44 \\
81 \\
-\quad \\
107 \\
71 \\
116 \\
208 \\
49 \\
92\end{array}$ & $\begin{array}{c}638^{* * *} \\
183^{* * *} \\
36 \\
30 \\
4 \\
67 \\
50 \\
31 \\
40 \\
35 \\
245\end{array}$ & $\begin{array}{r}517 \cdot 4 \\
141 \cdot 8 \\
43 \cdot 0 \\
45 \cdot 4 \\
2 \cdot 2 \\
73 \cdot 7 \\
54 \cdot 1 \\
28 \cdot 1 \\
31 \cdot 8 \\
41 \cdot 1 \\
242 \cdot 4\end{array}$ & $\begin{array}{r}123 \\
129 \\
84 \\
66 \\
182 \\
91 \\
92 \\
110 \\
126 \\
85 \\
101\end{array}$ \\
\hline All neoplasms & $140-239$ & $1125^{* *}$ & $1033 \cdot 1$ & 109 & $234^{* * *}$ & 187.9 & 125 & $1359^{* * *}$ & $1221 \cdot 0$ & 111 \\
\hline
\end{tabular}

${ }^{*} \mathrm{p}<0.05 .^{* *} \mathrm{p}<0.01$. $^{* * *} \mathrm{p}<0.001$

$p<0.01$ ). Tyre and general rubber goods sectors do, however, show a dissimilar occupational distribution of this excess. In the tyre industry occupation groups 5,7 , and 8 are chiefly affected whereas in the general rubber goods sector occupation groups 2 and 4 feature strongly in addition to 7 and 8 . Groups 2 and 4 identify the preparatory mixing and extruding stages of the manufacturing process and groups 7 and 8 the finishing and inspection stages.

Because of the small number of observations cohorts II and III do not contribute significantly to the excess of lung cancer. Only in occupation group
5 is there a small but just significant excess of lung cancer in the general rubber goods sector $(\mathrm{O}=5 \mathrm{E}$ $=1.8 \mathrm{p}<0.05)$.

\section{STOMACH CANCER}

With stomach cancer also, the greater part of the excess mortality $(\mathrm{O}=183 \mathrm{E}=141.8 \mathrm{p}<0.01)$ is to be found in cohort I (table 8). (Tyre sector: $\mathrm{O}=96 \mathrm{E}$ $=78.0 \mathrm{p}<0.05$ : general rubber goods sector: $\mathrm{O}=$ $22 \mathrm{E}=13.3 \mathrm{p}<0.01$ ). Owing, however, to the much smaller number of recorded deaths from this cause the analysis by occupation is rather less infor- 
Table 7 Lung cancer mortality: tyre and general rubber goods sectors by occupation and cohort. (ICD-8: 162.1, 163.0, 163.9) 3

\begin{tabular}{|c|c|c|c|c|c|c|c|c|}
\hline \multirow[t]{3}{*}{ Occupation group } & \multicolumn{4}{|l|}{ Cohort I } & \multicolumn{4}{|l|}{ Cohort II } \\
\hline & \multicolumn{2}{|l|}{ Tyre } & \multicolumn{2}{|c|}{ General rubber goods } & \multicolumn{2}{|l|}{ Tyre } & \multicolumn{2}{|c|}{ General rubber goods } \\
\hline & Obs & $\operatorname{Exp}$ & Obs & $\operatorname{Exp}$ & Obs & $\operatorname{Exp}$ & Obs & $\operatorname{Exp}$ \\
\hline $\begin{array}{r}1 \\
2 \\
3 \\
4 \\
5 \\
6 \\
7 \\
8 \\
9 \\
10\end{array}$ & $\begin{array}{c}6 \\
28 \\
9 \\
35 \\
134^{* *} \\
47 \\
17^{* *} \\
32^{* *} \\
24 \\
68\end{array}$ & $\begin{array}{r}4.9 \\
26.4 \\
12.8 \\
28.7 \\
103.6 \\
36.4 \\
8.3 \\
19.4 \\
19.0 \\
59.8\end{array}$ & $\begin{array}{c}2 \\
15^{* *} \\
2 \\
15^{* *} \\
18 \\
11 \\
7^{* *} \\
6^{*} \\
4 \\
16^{*}\end{array}$ & $\begin{array}{r}1.2 \\
6.8 \\
1.3 \\
7.2 \\
12.2 \\
7.3 \\
2.4 \\
2.4 \\
2.7 \\
8.7\end{array}$ & $\begin{array}{r}0 \\
10 \\
5 \\
8 \\
47 \\
18 \\
5 \\
9 \\
13 \\
15\end{array}$ & $\begin{array}{r}1.4 \\
9.5 \\
5.6 \\
8.1 \\
42.9 \\
15.5 \\
4.4 \\
9.5 \\
9.7 \\
20.9\end{array}$ & $\begin{array}{l}0 \\
3 \\
1 \\
1 \\
8 \\
8 \\
2 \\
2 \\
2 \\
5\end{array}$ & $\begin{array}{l}0.4 \\
3.1 \\
0.7 \\
3.7 \\
7 \cdot 0 \\
4.3 \\
1.2 \\
1.3 \\
1.8 \\
4 \cdot 1\end{array}$ \\
\hline All jobs & $\begin{array}{l}348^{* * * *} \\
\text { (SMR 124) }\end{array}$ & 279.8 & $\begin{array}{l}84^{* * *} \\
\text { (SMR 181) }\end{array}$ & $46 \cdot 4$ & $\begin{array}{l}120 \\
\text { (SMR 105) }\end{array}$ & $114 \cdot 6$ & $\begin{array}{l}30 \\
\text { (SMR 119) }\end{array}$ & $25 \cdot 2$ \\
\hline
\end{tabular}

${ }^{*} \mathrm{p}<0.05 .{ }^{* *} \mathrm{p}<0.01{ }^{* * *} \mathrm{p}<0.001$

mative than for lung cancer. In the tyre sector occupation groups 2,8 , and 9 in cohort I show statistically significant excesses as do also occupation groups 5 in cohort II and 9 in cohort III. The number of deaths occurring in the general rubber goods sector is so small that no individual occupation group has a statistically significant excess, but it will be seen that occupation groups 2,4 , and 5 are the major contributors to the overall significant excess in cohort I.

\section{BLADDER CANCER}

A full analysis of the deaths from bladder cancer has been provided here (table 9) because of the historical importance of this condition. Little information, however, may be derived from it. Only within the tyre sector of cohort I, in occupation groups 4 and 6 , is there any indication of a possible excess, and this observation is consistent with the hypothesis that only those men entering the industry before $\mathbf{1 9 5 0}$ (cohort I) could have been exposed to recognised bladder carcinogens that were withdrawn from production use in that year. There is no evidence of any continuing or residual bladder cancer hazard affecting those men who entered in cohorts II and III.

\section{OTHER CANCERS}

Other investigators in different countries have reported observing various excesses of cancer in rubber workers including cancer of the brain, prostate, colon, and rectum, and leukaemia. None of these findings can be substantiated from the data in the present study, although raised SMRs (nonsignificant) have been recorded for deaths from thyroid cancer (SMR $=182)$, oesophageal cancer $($ SMR $=126)$, and leukaemia $($ SMR $=110)$ (table 6).

The small number of deaths from thyroid cancer which all occurred in the tyre sector were not statistically significant $(\mathrm{O}=4 \mathrm{E}=2 \cdot 2)$ and cannot realis-

Table 8 Stomach cancer mortality: tyre and general rubber goods sectors by occupation and cohort. (ICD-8: 151)

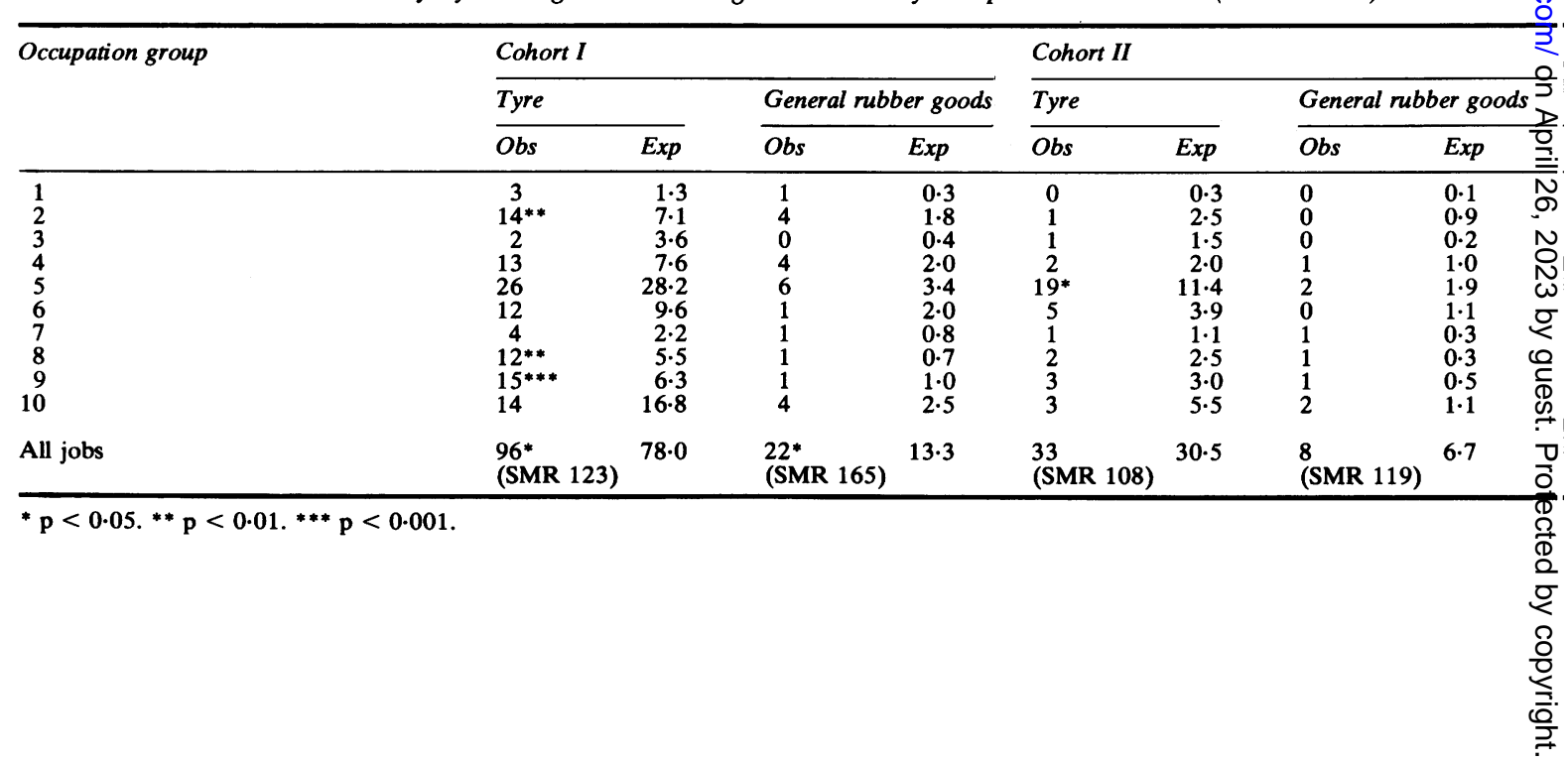




\begin{tabular}{|c|c|c|c|c|c|c|c|c|c|}
\hline \multicolumn{4}{|l|}{ Cohort III } & \multicolumn{6}{|c|}{ All cohorts } \\
\hline Obs & $\operatorname{Exp}$ & Obs & $\operatorname{Exp}$ & Obs & $\operatorname{Exp}$ & $S M R$ & Obs & Exp & $S M R$ \\
\hline $\begin{array}{r}2 \\
4 \\
1 \\
2 \\
18 \\
3 \\
3 \\
5 \\
8 \\
9\end{array}$ & $\begin{array}{r}0.5 \\
2.8 \\
1.4 \\
2.9 \\
15.4 \\
4.2 \\
2.6 \\
3.2 \\
4.9 \\
8.3\end{array}$ & $\begin{array}{l}0 \\
1 \\
0 \\
1 \\
5^{*} \\
1 \\
2 \\
0 \\
0 \\
0\end{array}$ & $\begin{array}{l}0.1 \\
0.6 \\
0.1 \\
1.7 \\
1.8 \\
1.7 \\
0.5 \\
0.4 \\
0.6 \\
1.5\end{array}$ & $\begin{array}{c}8 \\
42 \\
15 \\
45 \\
199 * * \\
68 \\
25^{*} \\
46^{*} \\
45 \\
92\end{array}$ & $\begin{array}{r}6.7 \\
38.7 \\
19.8 \\
39.7 \\
161.8 \\
56.1 \\
15.3 \\
32.1 \\
33.8 \\
89.0\end{array}$ & $\begin{array}{r}119 \\
109 \\
76 \\
113 \\
123 \\
121 \\
163 \\
143 \\
133 \\
103\end{array}$ & $\begin{array}{c}2 \\
19^{* *} \\
3 \\
17 \\
31^{*} \\
20^{*} \\
11^{* *} \\
8^{*} \\
6 \\
21\end{array}$ & $\begin{array}{r}1 \cdot 8 \\
10 \cdot 5 \\
2.1 \\
12 \cdot 5 \\
21 \cdot 0 \\
13 \cdot 2 \\
4 \cdot 1 \\
4 \cdot 1 \\
5 \cdot 1 \\
14 \cdot 3\end{array}$ & $\begin{array}{l}111 \\
181 \\
143 \\
136 \\
148 \\
152 \\
268 \\
195 \\
118 \\
147\end{array}$ \\
\hline $\begin{array}{l}47 \\
\text { (SMR 109) }\end{array}$ & $43 \cdot 3$ & $\begin{array}{l}9 \\
\text { (SMF }\end{array}$ & $8 \cdot 2$ & $515^{* * *}$ & $437 \cdot 7$ & 118 & $123^{* * *}$ & 79.7 & 154 \\
\hline
\end{tabular}

tically be regarded as a finding worthy of special comment. A different view must, however, be taken of the excess deaths attributable to oesophageal cancer (table 10) $(\mathrm{O}=40 \mathrm{E}=31.8)$ found both in the general rubber goods and in the tyre sectors. In the general rubber goods sector a statistically significant excess of these deaths was recorded for the whole of that industry sector $(O=10 \mathrm{E}=4.8$ p $<0.05$ ), and most of the deaths were concentrated in cohort $\mathrm{I}(\mathrm{O}=8 \mathrm{E}=2.8 \mathrm{p}<0.01)$. Half of these cohort I deaths may be related to employment in occupation group $6(\mathrm{O}=4 \mathrm{E}=0.4 \mathrm{p}<0.001)$.

In the tyre sector which produced a total of 30 deaths from oesophageal cancer, excesses were also apparent, being identified here in cohort II and occupation group $10(\mathrm{O}=4 \mathrm{E}=1.3 \mathrm{p}<0.05)$ and in cohort III associated with occupation group $9(\mathrm{O}$ $=4 \mathrm{E}=0.4 \mathrm{p}<0.001$ ).

In the case of leukaemia there is some evidence of an excess of deaths occurring in cohort III where the combined data for tyre and general rubber goods sectors shows that there were eight deaths observed and 3.2 expected $(p<0.05)$. There were, however, no more than two observed deaths in any one occupation group. In the absence of any similar evidence of excess in cohorts I and II it would be unwise to base any conclusions on this small excess in cohort III. There are no other statistically significant excesses recorded for the remaining cancer sites either in the cohort analysis or within the different industry and occupation groups.

\section{Discussion}

This study shares with other studies of a similar character several limitations that must be taken into account in the evaluation. National mortality rates, either for Scotland or for England and Wales, have been used to calculate expected deaths, but their validity for comparison with the mortality experi-

\begin{tabular}{|c|c|c|c|c|c|c|c|c|c|}
\hline \multicolumn{4}{|l|}{ Cohort III } & \multicolumn{6}{|c|}{ All cohorts } \\
\hline Obs & $\operatorname{Exp}$ & Obs & Exp & Obs & $\operatorname{Exp}$ & $S M R$ & Obs & Exp & $S M R$ \\
\hline $\begin{array}{l}1 \\
2 \\
1 \\
0 \\
7 \\
1 \\
2 \\
0 \\
6^{* *} \\
3\end{array}$ & $\begin{array}{l}0.1 \\
0.7 \\
0.4 \\
0.7 \\
4.0 \\
1 \cdot 0 \\
0.7 \\
0.8 \\
1.3 \\
2.1\end{array}$ & $\begin{array}{l}0 \\
0 \\
0 \\
0 \\
1 \\
1 \\
0 \\
0 \\
0 \\
0\end{array}$ & $\begin{array}{l}0.0 \\
0.1 \\
0.0 \\
0.4 \\
0.5 \\
0.4 \\
0.1 \\
0.1 \\
0.1 \\
0.3\end{array}$ & $\begin{array}{l}4 \\
17^{*} \\
4 \\
15 \\
52 \\
18 \\
7 \\
14 \\
24^{* * *} \\
20\end{array}$ & $\begin{array}{r}1.8 \\
10.3 \\
5.4 \\
10.4 \\
43.6 \\
14.7 \\
3.9 \\
9.0 \\
10.6 \\
24.2\end{array}$ & $\begin{array}{r}222 \\
165 \\
74 \\
144 \\
119 \\
122 \\
179 \\
156 \\
226 \\
83\end{array}$ & $\begin{array}{l}1 \\
4 \\
0 \\
5 \\
9 \\
2 \\
2 \\
2 \\
2 \\
6\end{array}$ & $\begin{array}{l}0.5 \\
2.8 \\
0.6 \\
3.4 \\
5.7 \\
3.5 \\
1.2 \\
1.2 \\
1.7 \\
3.9\end{array}$ & $\begin{array}{l}200 \\
143 \\
-147 \\
158 \\
57 \\
167 \\
167 \\
118 \\
154\end{array}$ \\
\hline $\begin{array}{l}22 * * \\
\text { (SMR 196) }\end{array}$ & $11 \cdot 2$ & $\begin{array}{l}2 \\
\text { (SMR 95) }\end{array}$ & $2 \cdot 1$ & $151^{* *}$ & 119.7 & 126 & $32^{*}$ & $22 \cdot 1$ & 145 \\
\hline
\end{tabular}


Table 9 Bladder cancer mortality: tyre and general rubber goods sectors by occupation group and cohort. (ICD-8: 188, 189.9)

\begin{tabular}{|c|c|c|c|c|c|c|c|c|c|c|c|c|c|c|c|c|}
\hline \multirow{3}{*}{$\begin{array}{l}\text { Occu- } \\
\text { pation } \\
\text { group }\end{array}$} & \multicolumn{4}{|c|}{ Cohort I } & \multicolumn{4}{|c|}{ Cohort II } & \multicolumn{4}{|c|}{ Cohort III } & \multicolumn{4}{|c|}{ All cohorts } \\
\hline & \multicolumn{2}{|l|}{ Tyre } & \multicolumn{2}{|c|}{$\begin{array}{l}\text { General } \\
\text { rubber goods }\end{array}$} & \multicolumn{2}{|l|}{ Tyre } & \multicolumn{2}{|c|}{$\begin{array}{l}\text { General } \\
\text { rubber goods }\end{array}$} & \multicolumn{2}{|l|}{ Tyre } & \multicolumn{2}{|c|}{$\begin{array}{l}\text { General } \\
\text { rubber goods }\end{array}$} & \multicolumn{2}{|c|}{ Tyre } & \multicolumn{2}{|c|}{$\begin{array}{l}\text { General } \\
\text { rubber goods }\end{array}$} \\
\hline & Obs & $\operatorname{Exp}$ & Obs & $\operatorname{Exp}$ & Obs & Exp & $O b s$ & $\operatorname{Exp}$ & $O b s$ & $\operatorname{Exp}$ & Obs & $\operatorname{Exp}$ & Obs & $\operatorname{Exp}$ & Obs & $\operatorname{Exp}$ \\
\hline 1 & 0 & 0.4 & 0 & $0 \cdot 1$ & 0 & 0.1 & 0 & 0.0 & 0 & 0.0 & 0 & 0.0 & 0 & 0.6 & 0 & 0.2 \\
\hline 2 & 2 & $2 \cdot 1$ & 0 & 0.5 & 1 & 0.7 & 0 & 0.2 & 1 & 0.2 & 0 & 0.0 & 4 & 3.0 & 0 & 0.8 \\
\hline 3 & 1 & $1 \cdot 1$ & 1 & 0.1 & 0 & 0.5 & 0 & $0 \cdot 1$ & 0 & 0.1 & 0 & 0.0 & 1 & 1.7 & 1 & 0.2 \\
\hline 4 & 5 & $2 \cdot 2$ & 1 & 0.6 & 0 & 0.7 & 0 & 0.3 & 2 & 0.2 & 0 & $0 \cdot 1$ & 7 & 3.1 & 1 & $1 \cdot 1$ \\
\hline 5 & 8 & $8 \cdot 2$ & 1 & 1.0 & 4 & $3 \cdot 5$ & 0 & 0.6 & 0 & $1 \cdot 3$ & 1 & 0.1 & 12 & 12.9 & 2 & 1.7 \\
\hline 6 & 5 & $2 \cdot 8$ & 1 & 0.6 & 0 & $1 \cdot 2$ & 0 & 0.3 & 0 & 0.3 & 1 & 0.1 & 5 & $4 \cdot 2$ & 2 & $1 \cdot 1$ \\
\hline 7 & 1 & 0.6 & 0 & 0.3 & 0 & 0.4 & 0 & 0.1 & 0 & 0.2 & 0 & 0.0 & 1 & $1 \cdot 2$ & 0 & 0.4 \\
\hline 8 & 1 & 1.7 & 0 & 0.2 & 0 & 0.8 & 0 & 0.1 & 0 & $0 \cdot 3$ & 0 & 0.0 & 1 & 2.9 & 0 & 0.4 \\
\hline 9 & 2 & $2 \cdot 1$ & 0 & 0.3 & 1 & $1 \cdot 1$ & 0 & 0.2 & 1 & 0.5 & 0 & 0.1 & 4 & 3.7 & 0 & 0.6 \\
\hline 10 & 5 & $5 \cdot 0$ & 0 & 0.8 & 2 & $1 \cdot 7$ & 1 & 0.3 & 0 & 0.7 & 0 & $0 \cdot 1$ & 7 & $7 \cdot 4$ & 1 & $1 \cdot 2$ \\
\hline All jobs & 24 & $23 \cdot 0$ & 1 & $4 \cdot 1$ & 6 & $9 \cdot 6$ & 1 & $2 \cdot 0$ & 3 & $3 \cdot 6$ & 1 & 0.7 & 33 & $36 \cdot 1$ & 3 & $6 \cdot 8$ \\
\hline
\end{tabular}

Table 10 Oesophageal cancer mortality: tyre and general rubber goods sectors by occupation and cohort. (ICD-8: 150)

\begin{tabular}{|c|c|c|c|c|c|c|c|c|c|c|c|c|c|c|c|c|}
\hline \multirow{3}{*}{$\begin{array}{l}\text { Occu- } \\
\text { pation } \\
\text { group }\end{array}$} & \multicolumn{4}{|c|}{ Cohort I } & \multicolumn{4}{|c|}{ Cohort II } & \multicolumn{4}{|c|}{ Cohort III } & \multicolumn{4}{|c|}{ All cohorts } \\
\hline & \multicolumn{2}{|l|}{ Tyre } & \multicolumn{2}{|c|}{$\begin{array}{l}\text { General } \\
\text { rubber goods }\end{array}$} & \multicolumn{2}{|l|}{ Tyre } & \multicolumn{2}{|c|}{$\begin{array}{l}\text { General } \\
\text { rubber goods }\end{array}$} & \multicolumn{2}{|l|}{ Tyre } & \multicolumn{2}{|c|}{$\begin{array}{l}\text { General } \\
\text { rubber goods }\end{array}$} & \multicolumn{2}{|l|}{ Tyre } & \multicolumn{2}{|c|}{$\begin{array}{l}\text { General } \\
\text { rubber goods }\end{array}$} \\
\hline & Obs & $\operatorname{Exp}$ & $O b s$ & $\operatorname{Exp}$ & $O b s$ & $\operatorname{Exp}$ & Obs & $\operatorname{Exp}$ & Obs & $\operatorname{Exp}$ & Obs & $\operatorname{Exp}$ & $O b s$ & $\operatorname{Exp}$ & Obs & $\operatorname{Exp}$ \\
\hline 1 & 1 & 0.3 & 0 & 0.1 & 0 & 0.1 & 0 & 0.0 & 0 & $0 \cdot 0$ & 0 & 0.0 & 1 & 0.4 & 0 & $0 \cdot 1$ \\
\hline 2 & 2 & $1 \cdot 5$ & 1 & 0.4 & 0 & 0.6 & 1 & 0.2 & 0 & $0 \cdot 2$ & 0 & 0.0 & 2 & $2 \cdot 4$ & 2 & 0.6 \\
\hline 3 & 1 & 0.8 & 0 & $0 \cdot 1$ & 0 & 0.4 & 0 & 0.1 & 0 & $0 \cdot 1$ & 0 & 0.0 & 1 & $1 \cdot 2$ & ( & $0 \cdot 1$ \\
\hline 4 & 0 & $1 \cdot 8$ & 2 & 0.4 & 0 & 0.5 & 0 & 0.2 & 0 & 0.2 & 0 & 0.1 & 0 & $2 \cdot 4$ & 2 & 0.8 \\
\hline 5 & 7 & $6 \cdot 3$ & 2 & 0.8 & 2 & $2 \cdot 7$ & 0 & 0.5 & 1 & $1 \cdot 1$ & 0 & 0.1 & 10 & 9.9 & 2 & $1 \cdot 3$ \\
\hline 6 & 2 & $2 \cdot 2$ & $4^{* * *}$ & 0.4 & 0 & $1 \cdot 0$ & 0 & $0 \cdot 2$ & 0 & 0.2 & 0 & $0 \cdot 1$ & 2 & $3 \cdot 4$ & $4^{* *}$ & 0.8 \\
\hline 7 & 1 & 0.5 & 0 & $0 \cdot 2$ & 0 & $0 \cdot 3$ & 0 & $0 \cdot 1$ & 0 & $0 \cdot 1$ & 0 & 0.0 & 1 & 1.0 & 0 & 0.3 \\
\hline 8 & 0 & $1 \cdot 2$ & 1 & 0.2 & 0 & 0.5 & 0 & 0.1 & 1 & 0.2 & 0 & 0.0 & 1 & $2 \cdot 0$ & 1 & 0.2 \\
\hline 9 & 1 & $1 \cdot 3$ & 0 & $0 \cdot 2$ & 1 & 0.7 & 0 & $0 \cdot 1$ & $4^{* * *}$ & 0.4 & 1 & 0.0 & $6^{*}$ & $2 \cdot 3$ & $i$ & 0.3 \\
\hline 10 & 3 & 3.6 & 1 & 0.5 & $4^{*}$ & $1 \cdot 3$ & 0 & $0 \cdot 2$ & 1 & 0.6 & 0 & $0 \cdot 1$ & 8 & $5 \cdot 4$ & 1 & $0 \cdot 8$ \\
\hline All jobs & 18 & $17 \cdot 0$ & $8^{* *}$ & $2 \cdot 8$ & 7 & $7 \cdot 1$ & 1 & $1 \cdot 6$ & 5 & $2 \cdot 9$ & 1 & 0.5 & 30 & $27 \cdot 0$ & $10^{*}$ & $4 \cdot 8$ \\
\hline
\end{tabular}

${ }^{*} \mathrm{p}<0.05$. $^{* *} \mathrm{p}<0.01$. $^{* * *} \mathrm{p}<0.001$.

ence of a defined industrial population is open to question partly because of local and regional variations in mortality and partly because of what has been described as the healthy worker effect. On the evidence of data derived from the present study, however, and as was shown in a recent study of acrylonitrile polymerisation workers, ${ }^{38}$ the selection of healthy workers for employment is probably not a factor of major importance in a study of cancer mortality. Furthermore, the application of latency criteria in this study has almost certainly diminished, if not eliminated, any healthy worker effect.

Most, although not all, of the factories participating in this study are within conurbations or urban areas, some of which have notably high SMRs for lung or stomach cancer. Such local variations in mortality rates cannot be taken into account in the analytical method in a study of the whole industry, but their possible influence on the findings should not be overlooked.
In the evaluation of the data relating to lung and bladder cancer mortality it would clearly have been an advantage to consider the possible influence of smoking. Information on smoking habit was, however, not available. Smoking is usually prohibited in rubber factories but smoking areas are provided for rest periods, and there are no grounds for thinking that the study population would differ greatly in smoking habit from the general population.

In this study social class specific mortality rates would have been more appropriate than those for the total population that have in fact been used. This omission of any allowance for social class may have introduced a bias into the results that would tend to exaggerate the importance and significance of some of the observed excesses of cancer. This could be of special relevance in relation to the observations on stomach cancer.

Since the discovery in 1950 of an excess of bladder cancer affecting rubber workers there has been 
continuing speculation about the possible presence of other and as yet unrecognised carcinogens in the industry. Natural rubber, talc, carbon black, mineral oils, and a wide range of other rubber chemicals used as compounding additives have all been under investigation, ${ }^{39-46}$ but none of these has so far been positively indicted. Exposure to polycyclic aromatic hydrocarbons may occur during rubber processing, ${ }^{45}$ and this probably results chiefly from using highly aromatic mineral oils (now a major component of many rubber compounds) that can be released into the factory atmosphere as a fume during the vulcanisation of rubber. Polycyclic aromatic hydrocarbons may under certain circumstances also be released from carbon black particles-to which they are normally tightly bonded-but epidemiological studies of carbon black workers ${ }^{478}$ have not thus far shown any evidence of excess cancer mortality.

Recent investigations of chemical exposure in the rubber industry have also shown that nitrosamines can be released into the factory atmosphere as a constituent of curing fume and can be identified at the $\mu \mathrm{g} / \mathrm{m}^{3}$ level. In September 1979 it was reported that when $\mathrm{N}$-nitrosodiphenylamine (NDPA) was used in rubber compounds, other and potentially more hazardous nitrosamines could be generated. ${ }^{49}$ In particular, it has been shown that NDPA may react with any secondary amines produced in the process to give the corresponding nitrosamine. Thus NDPA, if used with tetramethylthiuram disulphide (TMTD), may produce dimethylnitrosamine (NDMA) by nitrosation of dimethylamine. If used with 2(morpholino-thio)benzothiazole it will produce $\mathrm{N}$-nitrosomorpholine (NMOR). Under some conditions the concentrations of NDMA and NMOR have exceeded $100 \mu \mathrm{g} / \mathrm{m}^{3}$. Both of these nitrosamine compounds have been shown to be highly carcinogenic in animal and short-term tests.

Since it is considered that partial withdrawal or restrictions placed on the use of NDPA will not eliminate the danger-that is, that secondary amines, present as process constituents, might react with NDPA to produce nitrosamines-the BRMA has recently advised its members to discontinue the use of NDPA and to seek alternative materials.

The past experience in this industry of occupational bladder cancer justifies a special interest in this cause of death. It is now widely accepted that the excess of bladder cancer resulted principally from industrial exposure to carcinogenic aromatic amines and especially to betanaphthylamine that was present at a level of about $0.25 \%$ as an impurity in some complex organic chemicals used as rubber antioxidants before 1950 . The population studied in this report includes only a small number of men who could have been exposed to risk from these chemi- cals. These are the men in cohort I who entered the industry before 1950, some of whom will have worked on processes in which these antioxidants were used. Since however cohort I includes all men who entered at any time from January 1946 to December 1950 and since the suspect chemicals were withdrawn from production in 1949 it is clear that even in this group exposure will have been limited and of short duration. Since also the survival prospects of treated cases of bladder cancer have improved in recent years it is not surprising that the data from this study which examines only mortality and not morbidity should fail to provide convincing evidence of the hazard. What is noteworthy is that the only evidence of any excess of bladder cancer is confined to cohort I and that it appears within occupation groups 4 and 6 (those most likely to be exposed to fumes from heated rubber compound). The observation that no evidence of an excess of bladder cancer can be found in cohorts II and III is also highly important. Although since 1949 the industry has made no further use of the suspect antioxidants, it has continued to use suitable alternatives some of which, such as phenylbetanaphthylamine (PBNA), are now known to contain trace quantities of betanaphthylamine and some (acetonediphenylamine condensation products) which could, in theory at least, contain trace impurities of 4-aminodiphenyl. Furthermore, it has recently been shown ${ }^{50}$ that, in the case of PBNA, small amounts of betanaphthylamine, additional to that already present as an impurity, may be formed in the body by metabolism. The evidence presented here, however, and also that from other studies ${ }^{5142751}$ supports the view that continued use of compounds such as PBNA, which have a very low level of impurity (usually now $<1 \mathrm{ppm}$ ), does not constitute any enhanced risk of contracting bladder cancer.

Several studies in addition to this one have identified an excess of lung and stomach cancer in rubber workers, and it is an important observation that all of the recorded excess cancer mortality is accounted for in this study population by the excesses shown for these two cancer sites. From the concentration of the numerical and the statistically significant excesses of these cancers in cohort I the inference may be drawn that they are attributable to conditions of exposure that have undergone a steady improvement over the years and which are much less of a threat to the later intakes in cohorts II and III. Raised SMRs, however, even though they are based on a small number of observed deaths, are also present in the later cohorts, especially in the case of stomach cancer in the tyre sector of cohort III, and it is too early yet to discount the possibility that men working in the industry today may still be 
at risk. Further follow-up and observation of the study population is therefore required and are being undertaken.

There is at present insufficient evidence available to identify with any certainty the possible causes of the observed excesses of lung and stomach cancer. Although nitrosamines in curing fume, mineral oil vapour, carbon black, and French chalk are all candidates for further investigation it is, on the face of it at least, unlikely that it will prove possible, as in the case of bladder cancer, to identify a specific carcinogen. For this reason it may be important to consider not only the complex chemistry of the rubber manufacturing process but also the physical conditions in which the work is carried out. There is, for example, some evidence in this study that those men who work in the general rubber goods sector fare rather worse, in terms of their cancer mortality, than those making tyres. Although they contribute a much smaller proportion of the population-and hence fewer deaths-they have the highest SMRs both for lung and for stomach cancer and, in the case of lung cancer the pattern is maintained both for individual cohorts and for most individual occupation groups. It is therefore valid to consider whether or not there are any distinguishing features in the method of working in these two industry sectors that could account for the difference in their mortality experience.

In many respects the process of making a tyre is not dissimilar from the process of making general rubber goods. Both operations require the assembly and mixing of various chemicals with raw polymer, and the compound thus formed is usually then subjected to the processes of sheeting, extrusion, forming, and curing before emerging finally as the end product. The tyre industry, however, has certain advantages in that a smaller range of chemicals is likely to be required and a smaller number also of manufacturing processes. It is possible for weighing, mixing, and compounding operations to be more closely controlled and standardised and usually for fewer men to be employed in the largely automated tyre curing and vulcanising operations. In the two product groups the distribution of the observed excess of lung cancer by occupation does appear to reflect these differences. The excess observed in the general rubber goods sector in occupation group 2 (compound mixing) (a finding confirmed and commented on in the HSE study') is not seen in the tyre industry, but both sectors have an excess of lung cancer in those areas in which exposure to fume would be encountered.

The observed excesses of stomach cancer are more difficult to relate to job situation or product group. The fact that they appear chiefly in the tyre sector in occupation groups 2,8 , and 9 may indicate that exposure to dust rather than fumes is a significant factor, but the limited number of observations makes any attempt at more detailed evaluation highly speculative.

An excess of deaths from oesophageal cancer is now identified in both the tyre and the general rubber goods sectors of the industry, although different cohorts and different occupation groups are concerned in the excess. In the general rubber goods sector it is men who were engaged before 1950 and who have worked on the moulding and vulcanising of rubber goods who have experienced the greater part of this excess, whereas in the tyre sector it is the later entrants of cohorts II and III, and chiefly those concerned with plant maintenance and transport operations, who have been affected. At this distance in time it is not possible to characterise accurately the very variable environmental conditions that would have been experienced some 30 years ago by these occupation groups. There is, however, little doubt that exposure to curing fume would have been the principal feature of the general rubber goods occupation group 6 environment, and that work in occupation groups 9 and 10 in the tyre sector would necessarily mean at least occasional exposure to a combination of dust and fume in the environment, the intensity of which would be related to the very diverse operations associated with plant and engineering maintenance work. No explanation can at present be offered for the finding that the general rubber goods excess is seen only in the first entry cohort while the tyre industry excesses affect only cohorts II and III. Clearly there is a need for further studies to be carried out. Despite the now substantial accumulation, from many different sources, of epidemiological data on rubber workers, the observation of an excess of oesophageal cancer seems to have been reported in only one other recent study. ${ }^{52}$ Nevertheless its identification now in independent studies, carried out in two different populations of rubber workers, in different countries, must add considerable weight to the importance of the observation. The possibility that these oesophageal cancers might be causally associated with the observed excess of stomach cancer and with the recently identified presence in the factory environment of small quantities of carcinogenic nitrosamines merits consideration.

Over a period of many years industrial solvents have been extensively used in the rubber industrychiefly petroleum naphtha-but also other solvents including, in the past, benzene and carbon disulphide. The observation of an excess of leukaemia in association with exposure to solvents has been reported in the American rubber industry. ${ }^{16} 192253$ 
To date, however, there has been no confirmation of this finding in other countries, and it was not identified in the HSE census study in Britain. The small excess of leukaemia now seen in cohort III of this study merits further investigation. A preliminary study of the individual cases does not suggest the preponderance of any particular pathological type of leukaemia, and the fact that the observed cases were not concentrated in any single occupation group does not invite any inference of occupational aetiology. Furthermore, the imposition and enforcement of stringent controls on the use of benzene in recent years makes the total absence of any excess of leukaemia in cohort $\mathrm{I}(\mathrm{O}=15 \mathrm{E}=17 \cdot 2)$ inconsistent with the finding of an occupationally related excess in cohort III.

Excess cancers of the brain, ${ }^{54-56}$ large bowel, ${ }^{12}$ and prostate ${ }^{1825}$ have been reported by several authors. Although these cancer sites were also included in our analysis no evidence of any excess tumours has been found.

\section{Conclusions}

There is evidence in this study of an overall excess cancer mortality in the British rubber industry that is accounted for almost entirely by the observed excess of lung and stomach cancer. Apart from a small excess of oesophageal cancer there is no evidence of any significant excess cancer mortality for other cancer sites. The absence of any excess of bladder cancer affecting men who have entered the industry since 1950 is particularly noted and provides firm reassurance that measures then taken to remove from production use all suspect bladder carcinogens have been effective. Further follow-up of the study population to help in the more precise identification of occupational factors that may be responsible for the excess of lung and stomach cancer is clearly indicated.

We acknowledge with thanks the financial support for this study given by the member companies of the BRMA. Sincere thanks must also go to Paul A Cartwright, Felicity Bagenal, Patricia Kneen, Jane Toms, Angela Wilson, and David Cook, all of whom have contributed much to the successful completion of this study. We are greatly indebted to the OPCS for making available to us the follow-up and tracing facilities provided through the NHS Registry at Southport and also to the DHSS and staff of the NI Registry at Newcastle upon Tyne who kindly undertook much of the initial responsibility for tracing. In conclusion our thanks go especially to Mrs J Weir who has had the major responsibility for the correction, typing, and final production of the manuscript.

\section{References}

${ }^{1}$ Case RAM, Hosker ME. Tumours of the urinary bladder as an occupational disease in the rubber industry in England and Wales. Br J Prev Soc Med 1954;8:39-50.

${ }^{2}$ Case RAM. Tumours of the urinary tract as an occupational disease in several industries. Ann $R$ Coll Surg Engl 1966;39:213-35.

${ }^{3}$ Anonymous. Bladder cancer in the rubber industry. $\mathrm{Br} \mathrm{Med} J$ 1965;i:329-30.

4 Veys CA. Two epidemiological inquiries into the incidence of bladder tumours in industrial workers. $J$ Natl Cancer Inst 1969;48:219-26.

5 Veys CA. Bladder cancer in rubber workers: the story reviewed and up-dated. Plastics and Rubber Processing and Applications 1981;1:207-12.

' HM Chief Inspector of Factories. Annual report. London: HMSO, 1967:81

${ }^{7}$ Fox AJ, Lindars DC, Owen R. A survey of occupational cancer in the rubber and cable making industries; results of five-year analysis (1967-71). Br J Ind Med 1974;31:140-51.

- Fox AJ, Collier PF. A survey of occupational cancer in the rubber and cable making industries: analysis of deaths occurring in 1972-4. Br J Ind Med 1976;33:249-64.

9 Baxter PJ, Werner JB. Mortality in the British rubber industries 1967-76. London: Health and Safety Executive, HMSO, 1980.

${ }^{10}$ Burgess WA, Peters JM, Monson RR. The rubber workers study at the Harvard School of Public Health. In: Aye A, ed. Environmental aspects of chemical use in rubber processing operations. Washington: Office of Toxic Substances, Environmental Protection Agency, 1975:413-25.

$"$ Peters JM, Monson RR, Burgess WA, Fine LJ. Occupational disease in the rubber industry. Environ Health Perspect $1976 ; 17: 31-4$.

12 Monson RR, Nakano KK. Mortality among rubber workers. American Journal of Epidemiology 1976;103:284-303.

13 Monson RR. Effects of industrial environment on health. Environmental Law 1978;8:663-700.

14 Monson RR, Fine LJ. Cancer mortality and morbidity among rubber workers. $J$ Natl Cancer Inst 1978;61:1047-53.

${ }^{15}$ Fine LJ, Peters JM, Monson RR, Burgess WA. An industrial epidemiology. Chemtech 1980;10:298-301.

${ }^{16}$ McMichael AJ, Andjelkovich D, Tyroler HA. Cancer mortality among rubber workers: an epidemiologic study. Ann NY Acad Sci 1976;271:125-37.

17 Tyroler HA, Andjelkovich D, Harris R, Lednar W, McMichael AJ, Symons M. Chronic diseases in the rubber industry. Environ Health Perspect 1976;17:13-20.

18 McMichael AJ, Spirtas R, Gamble JF, Tousey PM. Mortality among rubber workers: relationship to specific jobs. JOM 1976;18: $178-85$.

${ }^{19}$ McMichael AJ, Spirtas R, Kupper LL, Gamble JF. Solvent exposure and leukaemia among rubber workers. JOM 1975;17:234-9.

${ }^{20}$ McMichael AJ, Spirtas R, Kupper LL. An epidemiologic study of mortality within a cohort of rubber workers 1964-72. JOM 1974;16:458-64.

${ }^{21}$ Harris RL. University of North Carolina Occupational Health Studies Programme. In: Ayer A, ed. Environmental aspects of chemical use in rubber processing operations. Washington: Office of Toxic Substances, Environmental Protection Agency, 1975:396-412.

22 Andjelkovich D, Taulbee J, Symons M. Mortality experience of a cohort of rubber workers 1964-73. JOM 1976;18:387-94.

${ }^{23}$ Andjelkovich D, Taulbee J, Symons M, Williams T. Mortality of rubber workers with reference to work experience. JOM 1977;19:397-405.

${ }^{24}$ Andjelkovich D, Taulbee J, Blum S. Mortality of female workers in a rubber manufacturing plant. JOM 1978;20:409-13. 
${ }^{25}$ Goldsmith DF, Smith AH, McMichael AJ. A case-control study of prostate cancer within a cohort of rubber and tire workers. JOM 1980;22:533-44.

${ }^{26}$ National Cancer Institute (DHEW). An epidemiologic study of leukaemia among rubber and tire industry workers. Chapel Hill, USA: Occupational Health Studies Group, School of Public Health, University of North Carolina, 1977.

${ }^{27}$ Checkoway H, Smith AH, McMichael AJ, Jones FS, Monson RR, Tyroler HA. A case-control study of bladder cancer in the United States rubber and tyre industry. $\mathrm{Br} \mathrm{J}$ Ind Med 1981;38:240-6.

${ }^{28}$ British Rubber Manufacturers' Association. Report on the health research project. Birmingham: BRMA Health Research Unit, 1976.

${ }^{29}$ Waterhouse JAH. Current status of cancer risk in the rubber industry. Advances in medical oncology, research and educaion. Vol 3. Oxford: Pergamon Press 1979;97-105.

${ }^{30}$ Monson RR. Occupational epidemiology. Florida, USA: CRC Press, 1980;35.

${ }^{31}$ World Health Organisation. Manual of the international classification of diseases, injuries and causes of death. Vols I, II. Geneva:WHO, 1947, 1957, 1967.

${ }^{32}$ Parkes HG. Health in the rubber industry. Birmingham: Rubber Manufacturing Employers' Association, Health Research Unit, 1966.

${ }^{33}$ Hill ID. Computing man years at risk. Br J Prev Soc Med 1973;26:132-4.

${ }^{34}$ Division of Epidemiology, Institute of Cancer Research. Serial mortality tables. Neoplastic diseases. Vol 1, England and Wales 1911-70. London: ICR, 1976.

${ }^{35}$ Office of Population Censuses and Surveys. Mortality surveillance 1968-75 England and Wales. London: OPCS Medical Statistics Division, 1977.

${ }^{36}$ Division of Epidemiology, Institute of Cancer Research. Serial mortality tables. Neoplastic diseases. Vol 4, Scotland 1911-70. London: ICR, 1976.

${ }^{37}$ Office of Population Censuses and Surveys. Occupational mortality 1970-2. London: HMSO, 1978:14.

${ }^{38}$ Werner JB, Carter JT. Mortality of United Kingdom acrylonitrile polymerisation workers. $\mathrm{Br} J$ Ind Med 1981;38:247-53.

${ }^{29}$ Duckrey H, Schmahl D, Mecke R. The carcinogenic effect of rubber after implantation into rats. Zeitschrift für Krebsforschung 1956;61:55-64.

${ }^{40}$ Blejer H, Arlon R. Talc: a possible occupational and environmental carcinogen. JOM 1973;15:92-7.
4 ' Boyland E, Carter RL, Gorrod JW, Roe JC. Carcinogenic properties of certain rubber additives. Eur J Cancer 1968;4:233-9.

${ }^{42}$ Kipling MD, Waldron HA. Polycyclic aromatic hydrocarbons in mineral oil, tar and pitch. Preventive Medicine 1976;5:262-78.

${ }^{43}$ Falk HL, Steiner PE. The identification of aromatic polycyclic hydrocarbons in carbon blacks. Cancer Res 1952;12:30-9.

${ }^{4}$ Haley TJ. Chloroprene: what is the evidence for its carcinogenicity? Clin Toxicol 1978;13:153-70.

${ }^{45}$ Nutt A. Measurement of some potentially hazardous materials in the atmosphere of rubber factories. Environ Health Perspect 1976;17:117-23

${ }^{46}$ Williams TM, Harris RL, Arp EW, Symons MJ, Van Ert MD. Worker exposure to chemical agents in the manufacture of rubber tires and tubes: particulates. Am Ind Hyg Assoc J 1980;41:204-11.

${ }^{47}$ Ingalls TH, Risquez-Iribarren R. Periodic search for cancer in the carbon black industry. Arch Environ Health 1961;2:429-33.

${ }^{48}$ Robertson J McD, Ingalls TH. A mortality study of carbon black workers in the United States from 1935 to 1974. Arch Environ Health 1980;35:181-6.

${ }^{49}$ Fajen JM, Carson CA. N-Nitrosamines in the rubber and tyre industry. Science 1979;205:1262-4.

${ }^{\text {so }}$ International Agency for Research on Cancer. Some aromatic amines and related nitro compounds. Monographs on the evaluation of carcinogenic risk of chemicals to man. Vol 16. Lyon: IARC 1978:325-41.

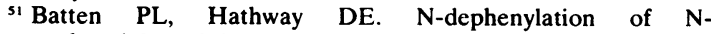
phenyl-2-naphthylamine in dogs and its possible oncogenic implications. Br J Cancer 1977;35:342-6.

${ }^{\text {s2 }}$ Delzell E, Monson RR. Mortality among rubber workers III Cause-specific mortality 1940-1978. JOM 1981;23:677-84.

${ }^{53}$ Wolf PH, Andjelkovich D, Smith A, Tyroler H. A case-control study of leukaemia in the US rubber industry. JOM 1981;23:103-8.

${ }^{54}$ Mancuso TF. Tumours of the central nervous system-industrial considerations. Acta Unio Internationale contre le Cancer 1963 ;xix:488-9.

${ }^{55}$ Lamperth-Seiler E. Urinary tract and brain neoplasms in workers of rubber plants. Schweiz Med Wochenschr 1974;104:1655-9.

${ }^{56}$ Bovet $\mathrm{P}$, Lob M. Mortality from malignant tumours amongst workers in a Swiss rubber goods factory-epidemiological study 1955-75. Schweiz Med Wochenschr 1980;110:1277-87. 